\title{
Application of Multimedia Network Technology in Chinese EFL Learners' Autonomous Learning of English Phonetics*
}

\author{
Fanghui $\mathrm{Hu}$ \\ Jining Medical University \\ Rizhao, China
}

\author{
Min Wang \\ Jining Medical Univeristy \\ Rizhao, China
}

\author{
Shanshan Li \\ Jining Medical Univeristy \\ Rizhao, China
}

\begin{abstract}
Learning English pronunciation and intonation is a basic link in EFL learning. The development of multimedia network technology provides Chinese EFL learners a new way to learning English phonetics and can meet each individual learning demand. Based on discussing the advantages of multimedia network technology, this paper focuses on application of multimedia network technology in Chinese EFL leaners' autonomous learning of English phonetics. Finally, some suggestions are put forward for colleges, teachers and students in terms of applying multimedia network technology to autonomous learning of English phonetics.
\end{abstract}

Keywords-multimedia network technology; EFL learners; English phonetics; autonomous learning

\section{INTRODUCTION}

As an important part of language structure, speech sounds of a language are the basis for communication, and they are the starting point for learning a language. However, in current China, the result of English phonetic teaching is under expectation. Mastering standard English pronunciation and intonation is still a difficulty for Chinese EFL (English as a Foreign Language) learners, partly due to the traditional English phonetics teaching that can't meet learners' needs in terms of teaching periods, methods and content.

In recent years, multimedia network technology has greatly developed, creating a new way to learn English phonetics. Because of the open-typed learner-centered learning environment and novel teaching methods, multimedia teaching has its great advantages [1]. Moreover, network can also provide abundant and updated information for learners.

Although multimedia network technology has already assisted English teachers in teaching phonetics, it is only

*This paper is sponsored by Planning and Research Project of Social Science of Shandong Province (15CWZJ21), Project of Reform in Education and Teaching (14054), Scientific Research Project (JY2013RW026), and Undergraduate Training Program for Innovation and Entrepreneurship (cx2016030) granted by Jining Medical University. confined to classroom teaching in which teachers mostly use courseware to present the way of pronunciation. Classroom teaching has its limitations; cultivating students' autonomous learning awareness and ability is the essence of education. Hence, how to adequately exploit multimedia network technology to efficiently assist Chinese EFL learners to autonomously learn English phonetics is still a subject attracting attention. This paper aims to discuss the application of multimedia network technology in Chinese EFL learners' autonomous learning English phonetics.

\section{Multimedia NeTwORK TECHNOLOGY AND AUTONOMOUS LEARNING}

Multimedia network technology is integration between multimedia technology and network technology; it groups together various media and network functions. Various information including written words, data, graphs, images, sound, and animated pictures is combined organically and transmitted interactively [2]. Multimedia network technology completely changed traditional teaching model, teaching means and the teacher-students role, making multimedia network teaching and learning possible. In the process of learning English phonetics, multimedia network technology plays a vital role. On one hand, multimedia network assembles functions of several media, and it can provide learners with enriched and excellent learning resources that can assist them to perceive and imitate standard English pronunciation and intonation. On the other hand, multimedia network can supply various medium exchange platforms. The popularity of the mobile communication of the fourth generation and wireless local area network, application of mobile communication terminals such as smart phones, Pads and son on, and development of multimedia instant messaging platforms such as WeChat and QQ proved to be beneficial for learning English phonetics.

It is firstly proposed by Holec, learner-autonomy means learners' ability of taking responsibility for their learning [3]. Although different researchers defined autonomous learning 
from different perspectives, it can be generalized as the process in which learners choose, monitor and reflect learning goals, learning content, learning methods, and learning process. According to Constructivism theory, learning is a process in which learners actively construct knowledge. Learners construct new cognition through interacting with the outside world based on their previous experience. However, everyone has his own way of construct knowledge owing to different social environment, cultural background and so on, and the constructed system will change with the development of emotion and cognition [4]. Therefore, autonomous learning is in accordance with not only cognitive rules but also psychological needs.

Multimedia network technology provides a good environment for constructing knowledge, making learners conveniently gain plentiful learning resources by quickly searching relevant information, and also learn knowledge through human-computer interaction and human-human interaction. So, multimedia network learning has obvious and true advantages [5].

\section{AdVANTAGES OF MUltimedia NETWORK \\ TECHNOLOGY IN AUTONOMOUS LEARNNING OF ENGLISH PHONETICS}

The goal of learning English phonetics for Chinese EFL learners is to bring about successful communication by mastering standard English pronunciation, stress, rhythm, intonation and so on. Perception of the features of English phones, stress, rhythm, and intonation, imitation of them, correction, re-imitation and consolidation are all very important links in learning English phonetics. Multimedia network technology can play an active role in these aspects because it conforms to the feature of autonomous learning of phonetic teaching [6]. The advantages brought about by multimedia network in autonomous learning English phonetics are as follows.

\section{A. Constructing Automomous Learning Platform}

Multimedia network technology provides learners with platforms for autonomous learning English phonetics. The equipment, technology and learning situations make it possible to autonomously learn phonetics.

Based on multimedia technology, phonetic teaching resources and speech interaction technology assist learners to perceive the phonetic characteristics of standard English and imitate them while network technology creates the environment for phonetic knowledge construction and learning situations. Learners become the real master of learning, and they can arrange their own learning according to their needs. That is to say, they can set learning goals, choose learning content, materials and methods, control learning time, place and tempo, evaluate learning content, environment, methods, and examine themselves on the platform of multimedia network.

\section{B. Helping Autonomously Learn in a Mobile Way}

As mobile telecom technology and other wireless technologies develops rapidly, mobile learning has become more and more practicable and turned into one kind of modern learning form. Mobile learning makes it possible for learners to interact with each other in many ways. Learners gain knowledge and experience from the devices or the field of social communication [7]. So, learning in a mobile way makes learning more experimental and abundant. What's more, mobile learning releases learners from a fixed place. That is to say, learners can learn freely anytime and anywhere with different purposes and in different ways.

When learning English pronunciation and intonation, learners can link addresses and view phonetic resources as long as they like. For example, if the learner wants to get to know how to pronounce a speech sound, he can quickly find the relevant audio material or the pronunciation picture of this sound on network. If the learner wants to imitate British English, he can also easily have access to it only by typing in the key words. In such a way, fragmentary time can be fully used to learn English pronunciation and intonation under the situation of mobile learning. The learning environment is mobile, and teachers, researchers, technicists and students are all mobile.

Hence, based on the multimedia network technology, autonomous learning of English phonetics becomes more and more convenient and learning efficiency is greatly improved as well. Besides, learners' enthusiasm will be triggered because of the abundance of the network learning resources and convenience to access to them.

\section{Constructing Interactive Learning Environment}

The outside of a learning environment is also important because learning itself is a process of constructing meaning, sharing and participating social cognition network. In addition, language input and output are essential when learning a foreign language. In the same way, when learning English phonetics, phonetic input and output are both needful. In the process of autonomous learning phonetics, learners have to choose phonetic materials of high quality as input only so can learners imitate correctly. What's more, in autonomous learning, interaction with teachers or classmates is also necessary. They can help you correct your pronunciation and give you some suggestions about how to learn it.

On the basis of multimedia network technology, phonetic learning is a combination of human-computer interactive learning and human-human interactive learning. When learning English pronunciation, learners firstly require abundant and standard English language input that can be supplied immediately by multimedia network technology. For example, a learner can imitate the intonation of a sentence again and again by playing sound or video media equipped in computers, tablets and smart phones; moreover, the learner can even do some phonetic exercises online to evaluate his own learning results and computers may record the learner's current phonetic proficiency and supply a proper individual learning plan or solve problems the learner may have. In addition, the interaction and communication between teachers and students and learning companions on instant massaging devices like WeChat and QQ will foster phonetic learning efficiency. 
All in all, multimedia network technology makes humancomputer interaction and human-human interaction convenient and fast. In the process of interactive learning, learners construct their own cognitive system and knowledge system.

\section{Helping Learn Phonetics in a Multimodal Way}

Chinese traditional English phonetic teaching mainly depends on a single mode of auditory sensation which easily causes students to lose interest in learning phonetics. New London Group first proposed multiliteracy and applied multimodality in language teaching [8].

Under the circumstances of multimedia network technology, phonetic teaching and learning become multimodal. For example, when learning an English speech sound, learners can master its pronunciation by looking at three-dimensional animation which can vividly shows the dynamic process of the movement of tongue, lips and so on. Besides, the differences between two similar sounds or between the native speaker and foreign language learner when pronouncing a sound can be perceived visually with the help of some phonetic software such as Praat.

In a word, phonetic learning based on multimedia network technology combines auditory mode and visual mode, together with description in words and imitation with sense of touch, can to a certain extent raise learners' interest in learning phonetics [9], and improve their aesthetic ability of English pronunciation.

\section{APPLICATION OF MULTIMEDIA NETWORK}

\section{TECHNOLOGY TO AUTONOMOUS PHONETICS LEARNING}

As there are some advantages brought about by multimedia network technology, the application of it into autonomous phonetic learning becomes pressing. The following is the discussion about how to improve efficiency of autonomous learning of English phonetics by applying this technology.

\section{A. Using Abundant Phonetic Learning Resources}

Abundant phonetic learning resources are of necessity in autonomous learning. Traditional learning resources mainly come from teachers and textbooks. They are relatively limited. In contrast, multimedia network can provide a large amount of various phonetic learning resources. For example, there are phones pronouncing demonstrations, and exercise for practicing segments, rhythm, stress, and intonation. There are even some animations showing the process of pronunciation. Film dialogues being dubbed, tongue twisters, English songs, essays and movies are all important excellent resources for learning English phonetics. Various forms of phonetic learning resources can also attract learners' attention. By learning online or downloading some of them, Chinese EFL learners can easily master English pronunciation skills and improve their pronunciation by practicing a lot.

So, in autonomous learning of English phonetics, EFL learners should apply these various phonetic resources, especially some dynamic pronouncing pictures and all kinds of audio phonetic materials by learning them online or downloading them.

\section{B. Constructing an Individualized Learning Way}

People learn a second or foreign language at different rates with different attainments due to different language aptitudes, learning motivation, use of strategies, age of acquisition and personality and even the time and efforts they spend on learning that language. So, learners should choose to use proper learning ways and learning materials according to their own situation, which belongs to individualized learning. Individualized learning requires learners to adopt efficient learning strategies and learning modes by taking learned knowledge and their own features into account [10]. For example, in some southern areas of China, EFL learners have difficulty in distinguish /l/ and /n/, $/ \mathrm{h} /$ and $/ \mathrm{f} /$, etc. Some learners can pronounce segments correctly, but they have some difficulties in mastering English stress and rhythm. In classroom teaching, it is impossible for teachers to consider learning situations of every student. So it is necessary and important for learners to construct individualized learning atmosphere with the help the multimedia network technology.

In autonomous learning phonetics, learners had better identify learning resources which are suitable for their current level and choose proper interactive learning modes provided by multimedia network technology.

\section{Creating Diversified Learning Environment}

Constructivism plays stress on constructing learning environment. Learning environment should be diversified, including constructing situations, supplying information resources, organizing cooperative learning and so on.

In learning English phonetics, learners are required to combine listening, pronunciation and oral expression together which will mobilize the learners' eyes, mouths, brains, ears and so on.

Multimedia network technology can provide diversified learning environment. On one hand, learners have access to multimodal learning environment full of lots of visual, auditory, vocal information and situations. In autonomous learning English phonetics, learners should make full use of this multimodal learning environment by looking at the pictures of pronunciation, listening to the phones, and imitating English intonation and rhythm. On the other hand, EFL learners can also improve their pronunciation and intonation by communicating with teachers, companions or even people from English-speaking countries. Diversified phonetic learning environment definitely benefits from multimedia network technology.

\section{SugGestions About How to ApPly Multimedia NeTwORK TECHNOLGOY INTO AUTONOMOUS PHONETIC LEARNING}

Applying multimedia network technology into autonomous phonetic learning is a complicated project, and it can be realized only by cooperation among colleges, teachers and students. 


\section{A. Constructing English Phonetic Learning Platform}

Colleges and universities are school-running subjects, bearing the responsibility to create excellent teaching condition. In application of multimedia network technology, colleges undertake the task of constructing the multimedia network platform and also take responsible for popularizing it.

Construction and application of multimedia network mainly include software and hardware. From the perspective of learners, relevant network transmission channels and multimedia application platform are essential because it is convenient for learners to search and browse multimedia resources and create diversified environment. A network teaching platform of English pronunciation, and intonation should be also developed so that the English phonological acquisition can be effective, creative and objective [11]. Therefore, based on previous multimedia technology platform, colleges should strengthen construction of phonetic platform.

Multimedia network laboratories can transmit phonetic knowledge vividly, interestingly and anticipatorily [12]. Autonomous phonetic learning platform can be constructed based on current language laboratories most colleges and universities have in China. Students can choose to learn in language laboratories or learn through linking the platform by smart phones or tablets.

In addition, colleges should assign professional multimedia network technology technicists to maintain relevant hardware and software devices so that learners can autonomously learn phonetics efficiently.

\section{B. Guiding Students to Learn English Phonetic Autonomously}

The development of autonomous learning experiences three periods. Practice and repetition insistently, reflect on learning tasks and totally focus on learning process. Most learners can't reach the goals in the third period independently. Namely, it is difficult for them to develop the autonomous learning ability without outside help.

Teachers play an important role in learning in that they are teaching subjects. Teachers have changed from introducing and instilling knowledge into helping and directing students to construct meaning [13].

Teachers should play an exemplary and guiding role in applying multimedia network technology. Firstly, teachers are users of multimedia network technology. In classroom teaching and out-of-class guiding, teachers should adopt this technology to create multimedia network teaching environment, which will influence students gradually. The awareness of using multimedia network technology to helping autonomous learning phonetics should be developed among English learners. Secondly, teachers should be constructor of multimedia network resources, integrating various phonetic learning resources and supply convenience for learners. For example, developing courseware of English phonetics is the basic responsibility that teachers should take [14]. Thirdly, teachers should construct the interactive learning environment. For example, it's better for teachers to be online for a certain time, answering questions of students, checking answers of some exercises students hand in online and so on. Most importantly, teachers should guide students to apply multimedia network technology to phonetic learning.

All in all, autonomous learning English phonetics with help of teachers' will become more and more efficient. Learners can also gain the confidence of autonomous learning of phonetics.

\section{Improving Awareness and Ability of Utilizing Multimedia Network Technology}

Learners or students are learning subjects, and users benefit from multimedia network technology. However, at present, learners have weak awareness of application of multimedia network technology and they are different in applying this technology. How the awareness and ability of using multimedia network technology are improved is an inevitable question.

As mentioned above, in order to improve the ability of utilizing multimedia network technology to help to learn English phonetics, learners can seek help from teachers. In addition, forming a learning team is a good way to solve this problem.

For example, phonetic learners can form learning teams in which there are several students and a teacher. The teacher assigns phonetic learning task, and team members finish the task using phonetic learning platform and members can also help each other to correct nonstandard pronunciation. Meanwhile, learners themselves should also be aware of the situation in which multimedia network technology has become an indispensable part in the future. After a period, students' ability and awareness of utilizing multimedia network technology will be improved.

\section{CONCLUSION}

With rapid development of information technology, multimedia network technology has been more and more influential on the learning behavior and learning effects. Multimedia network technology provides EFL learners with technical support in learning English phonetics and brings about new chances for English phonetic teaching reform. EFL learners should apply the multimedia to autonomous learning of phonetics, flexibly and properly using the abundant multimedia network learning resources, constructing interactive learning environment and developing individualized learning. Colleges, teachers and learners ought to work together to effectively utilize multimedia network technology to improve their aesthetic ability of English phonetics and help their autonomous learn of English phonetics.

\section{REFERENCES}

[1] C. Y. Shang, Y. H. Bu, X. M. Wang, "Promoting English phonetic teaching with multimedia", Journal of Jiangxi Finance College, 2009, Vol.22, No.6, pp. 206-207.

[2] Y. J. Jia, Fundamentals of Multimedia Technology, Beijing: Peking University Press, 2014, pp.10. 
[3] H. Holec, Autonomy and Foreign Language Learning, Oxford: Pergamon Press, 1981.

[4] L. David, Methods and Approaches of Autonomous learning, Fuzhou: Fujian education press, 2010, pp.15.

[5] Z. Q. Nong, "The network-based course of audio-visual English for students' autonomy”, Higher Education Forum, 2009, No.3, pp.99101 .

[6] H. L. Sui, "Multimedia technology and innovation of English Phonetics Teaching", foreign language research, 1997, No.2, pp.6567.

[7] L. T. Yu, "Using mobile technologies to create interwoven learning interactions: an intuitive design and its evaluation", Computer and Education, 2013, No.1, pp.1-13

[8] K. Cui, "Analysis of application of multimedia technology to College English phonetic teaching", Science and Technology, 2016, No.8, pp.214-215.

[9] C. W. Quan , X. N. Fan, "A study of multimodal phonetic teaching", Journal of Jiamusi Vocational College, 2016, No.8, pp. 366-367.

[10] M. X. Chen, J. D. Tan , "The change of students' learning style from the perspective of Constructivism", Journal of Hunan University of Science and Technology Press (social science edition), 2008, No.4, pp.124-127.

[11] A. L. Sun, "The functions and the system design of network teaching platform of English pronunciation and intonation", China Modern Education Equipment, 2013, No.23, pp.46-50.

[12] Y. L. Wei, "The application of multimedia voice room in English Phonetics Teaching in primary school", Journal of the Northwest Adult Education, 2013, No.3, pp.122-124.

[13] Y. L. Li, English learning strategies and autonomous learning, Shanghai: Shanghai Jiaotong University Press, 2011.

[14] M. Y. Huang, "CAI Application for English Phonetic teaching", Journal of Fuzhou Teachers College (Social Science Edition), 2000, Vol.20, No.1,pp.78-80. 